\title{
Perubahan Komunikasi Masyarakat dalam Inovasi Mitigasi Bencana (Studi pada Masyarakat di Wilayah Rawan Bencana Gunung Merapi sebelum dan setelah erupsi tahun 2010)
}

\author{
Damayanti Wardyaningrum \\ Program Studi Ilmu Komunikasi FISIP Universitas Al Azhar Indonesia
}

\begin{abstract}
Abstrak
Penelitian ini bertujuan untuk menganalisis perubahan komunikasi dalam inovasi mitigasi bencana. Dengan wilayah Indonesia yang memiliki banyak gunung berapi aktif dan terletak di wilayah padat penduduk, penelitian mengenai mitigasi bencana dari perspektif ilmu komunikasi sangat penting dilakukan. Inovasi dalam komunikasi dilakukan pada masyarakat di wilayah rawan bencana dengan adanya peristiwa erupsi gunung Merapi pada tahun 2010. Metode penelitian yang digunakan adalah deskriptif dengan pengumpulan data penelitian melalui observasi wilayah dan wawancara dengan masyarakat di dukuh Kalitengah Kidul, Desa Glagaharjo, Sleman, Daerah Istimewa Yogyakarta. Konsep yang digunakan adalah difusi inovasi, informasi dan mitigasi bencana. Hasil penelitian menunjukkan terdapat adopsi terhadap inovasi mitigasi bencana terkait dengan komunikasi masyarakat. Perubahan komunikasi terjadi pada alat komunikasi yang digunakan, sumber informasi untuk menentukan mengambil keputusan evakuasi, komunikasi kelompok masyarakat menentukan prosedur mitigasi bencana, sumber informasi tentang aktivitas gunung dan prioritas yang harus dilakukan pada saat tanggap darurat maupun masa pemulihan pasca bencana. Ditemukan dari hasil penelitian setelah erupsi tahun 2010 muncul sikap warga diwilayah rawan bencana yang lebih mandiri dan memiliki inisiatif dalam mengadopsi inovasi mitigasi bencana khususnya dalam hal komunikasi diantara masyarakat dalam menghadapi potensi bencana yang akan timbul.
\end{abstract}

Kata Kunci: perubahan komunikasi, difusi inovasi, informasi, mitigasi bencana

\begin{abstract}
Abtract
The research aim to analyze the changing of communication on the innovation of disaster mitigation. It is important for the research of disaster mitigation in communication perspective in high risk disaster area especially for the Merapi Volcanoe in Java for te eruption in 2010. This one of 129 active volcanoe in Indonesia, most located in Java. Due to the high density populations along the volcanoe area, means 120 million of people are in their risk potential and vulnerability. Since Indonesia region witnesses a large number of volcanoe disasters due to its geographical location and geological make up, thousand of people are affected by volcanoe disaster and result in number of deaths, suffering and economic losses. Moreover this disaster have their greatest economic and social impact in the poor area. The research use qualitative methods decriptive methode with interview to some of the people and to the formal and informal leader for data gathering. The result showing the understanding of social interaction of volcanoe disaster eruption situation that implies some particular diffusion of inovation in people communication such as group communication, communication tools, and the response in mitigation.
\end{abstract}

Key words: communication changes, diffusion of innovation, information and disaster mitigation 


\section{Pendahuluan}

Indonesia sebagai wilayah yang memiliki kondisi geografis, geologis, hidrologis, dan demografis yang rawan terhadap terjadinya bencana frekwensi yang cukup tinggi, memerlukan penanganan bencana yang sistematis, terpadu, dan terkoordinasi. Dalam pasal 1 Undang Undang no 24 tahun 2007 tentang Penanggulangan Bencana, yang dimaksud dengan bencana adalah "peristiwa atau rangkaian peristiwa yang mengancam dan menganggu kehidupan dan penghidupan masyarakat yang disebabkan baik oleh faktor alam, faktor non alam maupun faktor manusia sehingga mengakibatkan timbulnya korban jiwa manusia, kerusakan lingkungan, kerugian harta benda dan dampak psikologis". Dalam undangundang tersebut, juga ditetapkan tiga jenis bencana, yakni bencana alam, bencana non alam, dan bencana sosial.

Dari ketentuan di atas, bisa disimpulkan bahwa suatu peristiwa dianggap bencana jika peristiwa itu menimbulkan kerusakan, menimbulkan gangguan pada kehidupan, penghidupan, dan fungsi masyarakat yang mengakibatkan korban dan kerusakan melampaui kemampuan masyarakat setempat untuk mengatasinya dengan sumber daya yang dimiliki. Dapat disimpulkan bahwa kemampuan masyarakat dalam menghadapi bencana adalah hal yang penting. Dari perspektif ekonomi politik, suatu fenomena alam seperti badai, gempa banjir, tidak harus menjadi bencana. Peringatan, proteksi, pengetahuan, keahlian, akses, baik terhadap sumber-sumber material dan pengetahuan, jaringan dan sumber- sumber bantuan dapat memitigasi dampak kejadian alam dan meningkatkan kemampuan manusia untuk memulihkan efek yang ditimbulkan (Blaikie dalam Abdullah: 2008).

Salah satu bencana alam yang penting dikelola adalah letusan gunung berapi. Terdapat 127 gunung berapi aktif melingkari tanah nusantara. Tantangan tersebut sangat besar mengingat jumlah gunung api aktif (tipe A) di Indonesia mencapai 79 gunung dengan penyebaran sebagai berikut: Sumatera (13), Jawa (21), Bali (2), Lombok (1), Sumbawa (2), Flores (16), Laut Banda (8), Sulawesi(6), Kepulauan Sangihe (5), dan Halmahera (5).(Oman dkk, 2006). Dengan total 30 gunung berapi di pulau Jawa maka berarti terdapat 120 juta orang hidup dalam ancaman letusan gunung berapi. Kedekatan warga dengan lokasi gunung berapi telah terbukti fatal karena lebih dari 150.000 jiwa tewas akibat letusan gunung berapi diseluruh nusantara dalam kurun waktu 500 tahun terakhir. Angka ini merupakan rekor dunia (Kompas, 5 April 2015).

Dampak bencana alam dapat dikategorikan menjadi kerugian yang bersifat langsung, tidak langsung, dan kerugian yang berdampak fisik dan nonfisik pada lingkungan maupun sosial (Re Swiss dalam Olga Petrucci on Tiefenbacher, John, 2012). Kerugian yang bersifat langsung meliputi dampak fisik atau struktur bangunan. Kerusakan pada masyarakat berupa luka dan kematian. Sementara kerusakan yang bersifat tidak langsung adalah yang berdampak pada masyarakat sebagai akibat rusaknya sarana dan prasarana dan selanjutnya mengakibatkan kerugian usaha. Kerugian 
yang bersifat non fisik (intangible loss) adalah kerugian yang bersifat psikologis yang diakibatkan oleh kerugian langsung dan tidak langsung sebagai suatu penderitaan oleh individu.

Penelitian ini akan memfokuskan pada masyarakat yang tinggal di wilayah rawan bencana alam gunung berapi dengan kajian ilmu komunikasi. Selain data yang telah dikemukakan di atas, alasan penelitian dengan pemilihan tema tersebut akan disampaikan lebih lanjut dalam uraian di bawah ini. Terkait dengan persoalan mitigasi bencana alam di Indonesia, Ketua Pusat Studi Bencana Alam Universitas Gadjah Mada, Junun Sartohadi, mengemukakan bahwa sampai saat ini meskipun terdapat perbaikan dalam penanganan bencana, tapi belum terdapat perubahan besar terkait manajemen bencana. Pengelolaan bencana masih berbasis tanggap darurat, bukan mitigasi. Basis tanggap darurat itu pula yang menyebabkan penanganan bencana masih nampak kacau karena unsur perencanaan bukan menjadi unsur yang utama. Dengan melihat kompleksitas persoalan masyarakat di wilayah rawan bencana, mitigasi juga harus dipandang sebagai tindakan terkait dengan pendidikan bencana. Selama ini, pendidikan bencana lebih banyak dilakukan masyarakat yang sering kali tidak menggunakan basis keilmuan dan teknologi. Pemerintah bisa membuat perencanaan dengan kombinasi arahan dari atas maupun menggali partisipasi masyarakat. Hal Ini diperlukan agar ikatan-ikatan emosional di masyarakat bisa didekati, masyarakat juga bisa mengerti pendekatan birokrasi yang dilakukan pemerintah. Jika hal ini dilakukan, maka tidak terdengar pernyataan saling menyalahkan seperti ketika masyarakat Merapi menolak mengungsi. Dengan perencanaan komprehensif yang mencakup regional, pemetaan potensi bencana di wilayah masing-masing maka pemahaman atas potensi ancaman menjadi strategi mitigasi. Dalam perencanaan strategi mitigasi ini, pendekatan ilmiah dapat dipertemukan dengan usulan dari masyarakat (Kompas, 20-12-2010).

Mitigasi sendiri diartikan sebagai setiap tindakan yang berkelanjutan yang dilakukan untuk mengurangi atau menghilangkan resiko jangka panjang terhadap harta dan jiwa manusia. Dalam kaitan ini, mitigasi dapat dikatakan sebagai sebuah mekanisme agar masyarakat dapat menghindari dampak dari bencana yang potensial terjadi. Tindakannya dapat berfokus pada penghindaran bencana, khususnya menghindari penempatan manusia dan harta benda di daerah berbahaya. Termasuk usaha untuk mengendalikan bahaya melalui berbagai pembangunan fasilitas khusus dan penerapan teknologi tertentu (Wijanarko, 2006: 25).

Bagi masyarakat yang berada di wilayah rawan bencana, terdapat enam jenis kerentanan yang dihadapi dalam konteks sosial yang diuraikan oleh David dan Alexander dalam Özerdem dkk (2006). Pertama, kerentanan ekonomi, yaitu terdapat kondisi yang termarginalkan dalam memperoleh penghasilan selama terjadi bencana. Banyak penduduk yang kehilangan mata pencarian selama terjadi bencana. Kedua, kerentanan dalam bidang teknologi. Terdapat perbedaan akses terhadap teknologi antara level kelompok masyarakat. Antara kelompok kaya dan miskin, kelompok masyarakat yang tinggal di kota dan di perdesaan, negara kaya dan 
negara miskin, kelompok elit dan non elit. Keempat, adanya kemunduran atau ketertinggalan, yaitu kerentanan terhadap kemungkinan timbulnya keadaan yang membuat masyarakat menjadi tertinggal dan harus membangun kembali kehidupannya. Hal ini memerlukam bantuan dari institusi seperti pemerintah dan bantuan dana. Keempat, perpindahan penduduk atau masyarakat yang sebelumnya tidak memiliki pengalaman terhadap tanda-tanda bahaya akan menimbulkan generasi baru yang rentan (newly-generated vulnerabilities). Kelima, kerentanan yang muncul sebagai akibat dari keputusan untuk menolak norma-norma, aturan dan regulasi yang dianggap aman. Pada akhirnya, secara keseluruhan, kondisi kerentanan muncul pada peristiwa bencana yang sering hadir dan dianggap sebagai bukan hal yang penting yang sebenarnya menciptakan kondisi bahaya dalam kehidupan secara umum.

\begin{tabular}{lllr}
\multicolumn{2}{c}{ Sorensen dan } & Mileti & (dalam \\
Sorensen dkk, & 2006: & 213)
\end{tabular}
mengelompokkan tahapan bagaimana penduduk diwilayah rawan bencana merespon peringatan bahaya bencana sebagai berikut: a) mendengar adanya peringatan bahaya bencana; b)memahami isi pesan peringatan bahaya bencana; c) percaya pada peringatan yang dapat dipercaya dan akurat; d) memahami peringatan bahaya bencana untuk diri sendiri; e) mengkonfirmasi bahwa peringatan bahaya bencana benar dan yang lain diabaikan; dan f) melakukan tindakan perlindungan.

Beaudoin memberikan catatan tentang pentingnya komunikasi dan modal sosial dalam menghadapi bencana alam. Oleh karena dalam bencana terdapat unsur ketidakpastian, masyarakat membutuhkan informasi untuk mengetahui apa yang terjadi, memecah ketidakpastian dan membuat keputusan untuk bertahan hidup (Birowo \& Pramono, 2012). Hal ini juga tercantum UU no 24 tahun 2007 tentang Penanggulangan Bencana pada pasal 12 butir c yang menyebutkan bahwa Badan Nasional Penanggulangan Bencana mempunyai tugas menyampaikan informasi kegiatan kepada masyarakat.

Permasalahan komunikasi dalam situasi menghadapi bencana dikemukakan oleh Mercer dkk (dalam Tekauchi dll, 2009: 124). Dari hasil penelitian yang mereka kerjakan, Mercer dkk mengemukakan bahwa tanda-tanda tentang ancaman bahaya bencana vulkanik yang dituangkan dalam peta ternyata tidak dapat dipahami oleh masyarakat lokal. Masyarakat sebagai komunitas lokal memiliki persepsi berbeda dengan dengan pihak pembuat peta. Oleh karena itu, seharusnya, alatalat komunikasi yang dibangun dalam upaya pengurangan resiko bencana dibuat dengan kerjasama antara masyarakat lokal dan konsultan yang memahami masyarakat setempat agar dapat memberikan manfaat. Mercer dkk menyimpulkan bahwa untuk mencapai komunikasi yang efektif dan berkelanjutan dalam rangka membangun strategi pengurangan bencana perlu diupayakan untuk membangun cara komunikasi yang memadai dengan menggunakan metode tertentu agar terjalin kerjasama antar ilmuan dengan masyarakat setempat.

Kesimpulan penelitian Setyarto (2012) tentang komunikasi pada peristiwa bencana letusan gunung Merapi tahun 2010 menyebutkan bahwa beberapa istilah yang digunakan pemerintah dalam mitigasi bencana 
ternyata tidak dikenal oleh masyarakat seperti istilah resiko. Masyarakat setempat lebih akrab dengan istilah dampaknya seperti korban, kehilangan, kerusakan, dan sebagainya. Istilah mengungsi lebih dikenal daripada evakuasi. Selain itu, Istyarto juga menyarankan agar pengetahuan lokal dan science dapat bekerja sama menjadi "bahasa" pengungkapan suatu kebenaran tanda-tanda terjadinya erupsi. Terkait dengan pengetahuan lokal masyarakat mengenai bencana, penelitian Kusumaningtyas (2007) menemukan hal yang kurang lebih sama. Masyarakat memahami bencana berasal dari dongeng rakyat atau cerita turun temurun. Dalam keempat cerita rakyat yang diteliti (asal usul upacara Kasada di Gunung Bromo, Jawa Timur, Mad-mado di Nias,legenda kisah Atu Belah di Tanah Gayo Sumatera Utara dan Bujang Munang dari Nanga Serawai Kalimantan Barat), diperoleh temuan tentang pemahaman masyarakat lokal terhadap penyebab timbulnya bencana dan bagaimana cara mengatasinya.

Dalam kegiatan penyuluhan kepada masyarakat tentang Pengaruh Kepercayaan Lokal Terhadap Proses Evakuasi di wilayah Merapi, Miswanta dkk (2009) menguraikan hasil penelitiannya yang antara lain mengemukakan bahwa kepercayaan terhadap mitos tradisional masih melekat erat pada masyarakat sekitar Merapi dan tidak terdapat korelasi positif antara besarnya jumlah penduduk yang masih percaya mitos dengan frekuensi penyuluhan yang dilakukan oleh pemerintah. Bagi masyarakat di sekitar Merapi, mitos hanya sebagai faktor pendukung terganggunya kegiatan evakuasi bukan sebagai faktor penganggu utama.

Di jaman informasi dan teknologi yang telah berkembang pesat ini, akses informasi juga merupakan media yang tepat untuk menunjang kesimbangan alam. Sikap waspada terhadap kemungkinan terjadinya bencana alam didukung dengan penyebaran dan akses informasi yang memadai merupakan salah satu pemberian ruang kepada bencana untuk terjadi tanpa harus melukai dan mengorbankan manusia

(Kusumaningtyas, 2007: 14).

\section{Masalah Penelitian}

Undang-Undang

Republik

Indonesia Nomor 24 Tahun 2007 tentang Penanggulangan Bencana pasal 26 menyebutkan bahwa setiap orang berhak untuk mendapatkan informasi secara tertulis dan/atau lisan tentang kebijakan penanggulangan bencana dan pada bagian berikutnya disebutkan bahwa setiap orang berhak untuk berpartisipasi dalam pengambilan keputusan terhadap kegiatan penanggulangan bencana, khususnya yang berkaitan dengan diri dan komunitasnya. Selain itu, terkait dengan komunikasi dalam mitigasi bencana dalam pasal 27 juga tercantum bahwa setiap orang berkewajiban untuk memberikan informasi yang benar kepada publik tentang penanggulangan bencana. Pasal 21 menyebutkan bahwa Badan Penanggulangan Bencana Daerah mempunyai tugas: menyusun, menetapkan, dan menginformasikan peta rawan bencana dan pada bagian lain disebutkan bahwa tugas lainnya adalah melaporkan penyelenggaraan penanggulangan bencana kepada kepala daerah setiap sebulan sekali dalam kondisi normal dan setiap saat dalam kondisi 
darurat bencana. Perubahan komunikasi masyarakat sebagai bentuk pengetahuan baru atau inovasi dalam mitigasi bencana terutama pada wilayah yang memiliki siklus bencana rutin. Oleh karena itu, penting untuk dilakukan kajian mengenai bagaimana perubahan komunikasi masyarakat diwilayah rawan bencana?

\section{Tujuan Penelitian}

Penelitian bertujuan untuk menganalisis perubahan komunikasi masyarakat dalam inovasi mitigasi bencana. Periode waktu yang menjadi elemen penting dari difusi inovasi mitigasi bencana ini adalah pada saat sebelum dan setelah erupsi gunung Merapi tahun 2010. Dari hasil analisis ini, diharapkan dapat diperoleh gambaran hal-hal penting apa saja yang menjadi perubahan dalam komunikasi masyarakat terutama dalam bersikap dan berperilaku terhadap informasi dalam menghadapi resiko bencana letusan gunung Merapi yang pada tahun 2010 mengalami erupsi besar. Selanjutnya, hasil penelitian ini diharapkan dapat memberikan rekomendasi yang bermanfaat untuk mitigasi bencana.

\section{Manfaat penelitian}

Selain memberikan manfaat bagi pengembangan kajian mengenai mitigasi bencana dari persepektif komunikasi, penelitian ini juga diharapkan memberikan manfaat praktis proses mitigasi bencana bagi masyarakat. Pertama, memberikan gambaran tentang perubahan komunikasi masyarakat sebelum dan sesudah erupsi Merapi pada 2010. Kedua, dapat digunakan sebagai salah satu rekomendasi dalam meningkatkan mitigasi bencana dari segi komunikasi bagi masyarakat di wilayah rawan bencana. Ketiga, sebagai bahan masukan pembuat kebijakan mengenai mitigasi bencana yang berkembang dari waktu kewaktu sering dengan perubahan perilaku masyarakat serta tingkat kerentanan terhadap bencana.

\section{Konsep Penelitian}

Penelitian ini bersandar pada tiga kerangka konseptual pokok, yakni difusi inovasi, informasi, dan mitigasi bencana. Ketiga konsep utama ini akan dipaparkan sebagai berikut.

\section{Difusi Inovasi}

Inovasi memberikan berbagai kemungkinan sebuah alternatif baru atau beberapa alternatif bagi individu atau organisasi sebagai salah satu alat untuk membantu memecahkan masalah. Dalam mitigasi bencana, permasalahan yang begitu kompleks muncul dan perlu memperoleh pemecahan. Masalah muncul dari mulai situasi adanya potensi bencana atau pada fase kesiapsiagaan bencana, tahap terjadinya bencana atau tanggap darurat, tahap pemulihan atau recovery hingga pada fase normal dimana belum ada potensi terjadinya bencana.

Difusi adalah proses dimana inovasi dikomunikasikan melalui beberapa saluran yang dilakukan sepanjang waktu diantara anggotaanggota dalam sistem sosial. (Rogers, 1995:10). Sehingga terdapat empat elemen penting didalam difusi, yaitu inovasi, saluran komunikasi, waktu dan sistim sosial. Inovasi bisa merupakan suatu ide, kegiatan praktis atau objek yang dipahami sebagai sesuatu yang baru oleh individu atau unit yang mengadopsi. Kebaruan dari suatu ide bagi individu maka disebut sebagai inovasi. Kebaruan suatu inovasi bukan hanya dapat dilihat dari pengetahuannya, tapi dapat ditinjau dari elemen persuasinya dan keputusan untuk 
mengadopsi inovasi. Selain itu, inovasi sendiri memiliki lima karakteristik tertentu yang dapat dipahami oleh individu yang dapat menjelaskan perbedaan kecepatan dalam mengadopsinya.

Saluran komunikasi, dalam kerangka difusi inovasi, di sisi lain, didefinisikan sebagai proses dimana para peserta menghasilkan dan berbagi informasi antara satu dengan yang lain untuk mencapai saling pemahaman. Difusi merupakan salah satu tipe komunikasi dimana isi pesan yang dipertukarkan fokusnya adalah tentang ide-ide baru.

Waktu terkait dengan proses difusi. Pada beberapa riset tentang perubahan perilaku, unsur waktu bahkan sering diabaikan. Namun, pada beberapa penelitian tentang difusi, waktu merupakan kekuatan dari terjadinya difusi. Ada tiga proses penting dalam proses difusi inovasi ini yang perlu diperhatikan. Pertama, proses keputusan inovasi dimana individu melalui tahapan dari pengetahuan awal mengenai inovasi sampai kepada adopsi atau penolakan. Kedua, dalam proses adopsi inovasi, perlu diperhatikan kecepatan dan kelambatan individu atau unit dalam mengadopsi inovasi dibandingkan dengan anggota lainnya. Ketiga, untuk proses tingkat kemampuan mengadopsi inovasi, ukuran jumlah anggota dalam satu sistem yang mampu mengadopsi inovasi diukur dalam periode waktu.

Dengan mendasarkan uraian Rogers dan Kincaid (Rogers, 1995: xvi), Rogers mengemukakan bahwa hampir semua penelitian tentang difusi inovasi pada masa lalu berbasiskan pada model komunikasi linear dimana proses pesan mengalir dari sumber ke penerima pesan seperti dalam model komunikasi satu arah. Berbagai bentuk difusi dilakukan secara konsisten seorang individu yang merupakan agen perubahan dalam menginformasikan ide baru kepada calon adopter yang potensial. Namun, bentuk lain difusi digambarkan secara lebih akurat dengan model konvergeni dimana komunikasi didefinisikan sebagai sebuah proses dimana partisipan menghasilkan dan membagi informasi dengan pihak lain untuk mencapai saling pengertian sehingga pada kajian yang ada saat ini tercapai sebuah konsep tentang difusi menggunakan model konvergensi ddengan menekankan adanya pertukaran informasi diantara partisipan dalam proses komunikasinya.

\section{Informasi}

Dari perspektif sejarah, terdapat beberapa pengertian tentang informasi yang diantaranya dikemukakan oleh Shanon (Ritchie, 1991: 6-8) yang memandang informasi dari terminologi mekanik. Komunikasi antarmanusia memiliki elemen-elemen seperti sinyal, transmisi, encoding dan decoding. Sementara itu, Weaver mengembangkan konsep tersebut dengan menekankan bahwa perlu ditambahkan elemen mengenai arti dari informasi dan bagaimana informasi dapat berjalan dengan efektif sehingga komunikasi bukan hanya sekadar transmisi secara fisik. Berdasarkan konsep Shanon, pemahaman informasi menjadi kurang lengkap karena makna informasi tidak terpenuhi sehingga dibutuhkan elemen lain, yaitu bagaimana informasi dapat memberikan arti dan dapat berjalan efektif seperti yang dikehendaki oleh pengirim pesan.

Konsep lain tentang informasi menyebutkan bahwa informasi dapat 
dianggap sebagai sejumlah pilihan atau alternatif yang digunakan untuk memprediksi suatu hasil. Dalam situasi yang kompleks dengan berbagai macam kemungkinan hasil, informasi lebih banyak tersedia dibandingkan dengan pada situasi yang sederhana dan dengan kemungkinan hasil yang lebih sedikit. Semakin banyak informasi yang dimiliki, maka kemungkinan alternatif yang diperoleh akan semakin banyak (LittleJohn \& Foss, 2002: 42) sehingga dalam konsep transmisi informasi, fokus kajiannya bukan mengenai arti dari sebuah informasi namun hanya terfokus pada bagaimana informasi dipindahkan dan diterima, dan informasi akan membantu dalam mengurangi ketidakpastian.

Sikap seseorang itu sendiri terhadap informasi dipengaruhi oleh dua variable, yaitu arah kecenderungan (valence) dan bobot nilai (weight). Arah kecenderungan ini akan menentukan bagaimana sikap seseorang dalam menerima informasi yang diperoleh terhadap kepercayaannya. Jika informasi yang diperoleh mendukung kepercayaan seseorang, maka sikapnya akan positif. Sebaliknya, jika informasi yang diperoleh bertentangan dengan kepercayaannya maka informasi akan ditolak. Kemudian terkait dengan bobot (weight) informasi, hal ini terkait dengan fungsi kredibilitas terhadap informasi. Jika informasi yang diterima dianggap benar maka akan menambah nilai sikap seseorang terhadap kepercayaannya. Sebaliknya, jika informasi yang diterima dianggap salah maka akan menurunkan bobot penilaian terhadap kepercayaan seseorang mengenai sesuatu hal sehingga dapat disimpulkan bahwa unsur arah kecenderungan (valence) menentukan bagaimana (how) arah sikap sesorang terhadap sesuatu). Bobot nilai (weight), di sisi lain, menentukan seberapa besar (how much) sikap seseorang terhadap sesuatu.

Studi mengenai informasi sedemikian penting dalam kajian komunikasi karena adanya perbedaan yang signifikan ketika harus menentukan pilihan dari beberapa alternatif yang ada. Peluang untuk mengurangi ketidakpastian ketika seseorang harus menentukan pilihan atau mengambil keputusan dapat dilakukan dengan permrosesan informasi (Rogers dan Kincaid,1981: 48). Hal ini dapat dijelaskan antara lain ketika seseorang harus menentukan pilihan dari berbagai alternatif yang ada seringkali keputusan dapat diambil setelah adanya informasi. Bahkan keputusan dapat berubah atau berbeda hanya karena adanya informasi yang membedakan antara alternatif yang satu dengan alternatif yang lain.

Bateson (dalam Rogers dan Kincaid, 1981: 49) menegaskan bahwa perbedaan dapat terjadi karena adanya informasi. Penjelasan yang dapat disimpulkan dari Bateson adalah bahwa informasi menciptakan perbedaan mengenai seuatu hal. Seseorang memiliki sikap yang berbeda dari orang lain atau mengambil keputusan yang berbeda adalah karena ketersediaan informasi atau dari informasi yang diperoleh. Pada tahap selanjutnya, argumentasi ini memberikan penjelasan yang lebih luas bahwa dengan informasi dapat mengurangi ketidakpastian sesuai dengan terminologi yang dikemukakan oleh Pearson \& Nelson (Ritchie, 1991: 3). Konsep informasi dalam komunikasi merupakan terminologi untuk menjawab pertanyaan dan mengurangi ketidakpastian.

Teori pengurangan ketidakpastian (uncertainty reduction) yang dikemukakan 
oleh Berger dan Calabrese (Miller, 2005: 176) memberikan cakupan dan tujuan yang meliputi bentuk model proses interaksi dalam pengembangan relasi. Dalam teori tersebut, Berger dan Calabrese menyebutkan bahwa teori ini menggunakan asumsi bahwa setiap orang ketika berelasi dengan orang lain yang masih asing didorong oleh keinginan untuk mengurangi ketidakpastian diantara satu sama lain. Unsur ketidakpastian tersebut meliputi kognitif dan perilaku. Ketidakpastian dari segi kognitif adalah pada unsur kepercayaan dan sikap satu sama lain, sedangkan ketidakpastian dalam hal perilaku adalah bagaimana orang lain akan bertindak dalam interaksi satu sama lain. Pengembangan teori ini dilakukan oleh Berger yang memberikan perhatian pada konsep tentang strategi untuk memperoleh informasi dalam rangka mengurangi ketidakpastian. Dalam mencapai penyebaran informasi yang optimal, diperlukan peran opinion leader yang dapat menularkan informasi kepada kelompok. Peran opinion leader dalam penularan informasi merupakan salah satu elemen dalam proses integrasi informasi seperti tentang kredibiltas seseorang, maupun posisi opinion leader sebagai pihak yang informasinya dapat menambah keyakinan penerima informasi mengenai sesuatu hal yang telah diketahu sebelumnya.

Salah satu elemen dalam konsep komunikasi adalah mengenai informasi yang dikemukakan oleh Chafee (1991:3). Dengan mengutip penjelasan Dooglas, Chafee mengemukakan bahwa informasi termasuk didalamnya adalah data, pengetahuan dan opini. Selain itu, informasi juga digunakan untuk menjawab pertanyaan dan mengurangi ketidakpastian, sehingga informasi harus memiliki keterkaitan antara sesuatu yang tidak diketahui dengan sesuatu yang sudah diketahui sebelumnya.

\section{Bencana dan Mitigasi Bencana}

Menurut

Undang-undang

Republik Indonesia No 24 Tahun 2007 Tentang Penanggulangan Bencana, pasal 1 menyebutkan bahwa bencana adalah peristiwa atau rangkaian peristiwa yang mengancam dan mengganggu kehidupan dan penghidupan masyarakat yang disebabkan baik oleh faktor alam danatau faktor nonalam maupun faktor manusia sehingga mengakibatkan timbulnya korban jiwa manusia, kerusakan lingkungan, kerugian harta benda, dan dampak psikologis. Selanjutnya, pasal 2 menyebutkan bahwa bencana alam adalah bencana yang diakibatkan oleh peristiwa atau serangkaian peristiwa yang disebabkan oleh alam antara lain berupa gempa bumi, tsunami, gunung meletus, banjir, kekeringan, angin topan, dan tanah longsor.

Mitigasi sendiri diartikan sebagai setiap tindakan yang berkelanjutan yang dilakukan untuk mengurangi atau menghilangkan resiko jangka panjang terhadap harta dan jiwa manusia. Sehingga mitigasi dapat dikatakan sebagai sebuah mekanisme agar masyarakat dapat menghindari dampak dari bencana yang potensial terjadi. Tindakannya dapat berfokus pada penghindaran bencana, khususnya menghindari penempatan manusia dan harta benda di daerah berbahaya. Termasuk usaha untuk mengendalikan bahaya melalui berbagai pembangunan fasilitaS khusus dan penerapan teknologi tertentu (Wijanarko 2006: 25).

Sylves (2008: 21) mengemukakan bahwa dalam mitigasi tercakup keputusan 
untuk melakukan apa dan dimana terkait masalah kesehatan, keamanan dan kesejahteraan dari masyarakat yang telah ditentukan dan dilaksanakan sebagai program pengurangan resiko. Hal ini merupakan tindakan yang berkelanjutan untuk mengurangi resiko terhadap jiwa dan harta benda serta dampaknya. Hal lain yang penting terkait dengan mitigasi adalah perhitungan efektifitas biaya yang dikeluarkan dengan pengurangan resiko yang akan terjadi, termasuk kemungkinan resiko fisik dan sosial dimasa yang akan datang.

Claude Gilbert menyodorkan ringkasan konsep tentang bencana (Porfiriev dalam Quarantelli, 1998:5 8) dalam tiga paradigma. Paradigma pertama menyebutkan bahwa bencana adalah merupakan hasil atau akibat dari suatu tekanan eksternal. Paradigma kedua menyebutkan bahwa akibat kerentanan sosial dan ketiga akibat dari ketidakpastian. Konsep ini masih senada dengan Pelanda yang dikutip dari sumber yang sama yang mengintepretasikan bencana sebagai akibat kondisi sosial dan lingkungan yang buruk, tekanan kolektif dari sebuah komunitas, adanya perbedaan dalam kapasitas untuk menangani kerusakan dan akibat negatif yang ditimbulkan.

Bencana dapat mucul secara cepat dengan hanya sedikit peringatan awal atau tanpa ada peringatan sebelumnya sama sekali. Namun, sebagian besar dampak proses bencana terjadi dalam waktu cepat seperti bencana gempa bumi, tsunami, vulkanik, tanah longsor, badai dan banjir. Jenis bencana dengan proses yang lebih lambat terjadi karena ketidakmampuan negara dalam merespon kebutuhan masyarakat yang terjadi. Disisi lain, terdapat bencana yang dampaknya memerlukan penanganan dalam hitungan minggu dan bulan bahkan tahun. Misalnya kelkeringan, kelaparan, epidemic penyakit dan erosi lahan.

Beberapa ahli sosial menekankan pemahaman tentang bencana sebagai sebuah konstruksi sosial. Bagi para ahli ini, bencana dilihat sebagai dampak proses sosial atau konsekuensi sosial yang menghasilkan bahaya, atau meningkatkan kerentanan dari sebuah sistem sosial dari dampak suatu bahaya (Porfiriev in Quarantelli, 1998: 59). Berdasarkan kajian konsep dan pragmatis tentang bencana, Quarantelli merumuskan bencana sebagai berikut.

A state/condition destabilizing the social system that manifest itself in malfunctioning or disruption of connection and communications between its elements or social units (communities, social groups, and individuals), partial or total detruction/demolition, physical and psychological overload suffered by some of these elements; thus, making it necessary to take extraordinary or emergency counter measures to reestablish stability.

Dalam situasi bencana dimana diperlukan tindakan yang sifatnya extraordinary, informasi sangat diperlukan. Malloney dan Capola (2009: 18), misalnya, mengemukakan, "Once an audience is informed sufficiently and appropriately about a hazard, they are primed to receive and process information that will help them take appropriate action to reduce their vulnerability to one or more hazard risk." Peringatan dini membuat masyarakat menjadi lebih waspada dan tersedianya informasi resmi untuk kemudian mengambil tindakan yang tepat. 
Peringatan dini dibangun untuk mentransmisikan pesan kepada semua pihak dimanapun dan kapanpun. Dengan menggunakan berbagai macam sistem dan kolaborasi antara masyarakat, pemerintah, lembaga non pemerintah, pihak swasta akan meningkatkan kemampuan sistim komunikasi dalam mencapai target sasaran masyarakat.

Agar suatu pesan mengenai bencana bisa diterima dengan efektif, ada beberapa syarat yang harus dipenuhi. Pertama, perlu adanya kepercayaan masyarakat terhadap pihak yang menyampaikan pesan (trustworthy). Kedua, pihak yang menyampaikan pesan adalah pihak yang dianggap memiliki kewenangan atau kualifikasi sebagai pengirim informasi, karena setiap individu bebas untuk memilih siapa pihak yang ingin didengarnya. Ketiga, tidak adanya kepentingan untuk memperoleh sesuatu dari informasi yang disampaikan. Masyarakat harus merasa yakin bahwa informasi yang diperoleh tidak memiliki kepentingan tertentu (free of personal gain). Keempat, informasi yang disampaikan hendaknya akurat, dapat dikonfirmasi bahkan dapat didukung oleh data-data. Kelima, konsistensi dalam penyampaian pesan, terutama pesan yang disampaikan secara berulang. Pesan yang disampaikan melalui media yang berbeda seperti radio, cetak, internet berisi konten yang sama. Enam, pesan disampaikan berulang-ulang untuk memberikan pemahaman bagi masyarakat (repetitive). Tujuh, pesan hendaknya mudah dipahami (easily understood) dengan mempertimbangkan faktor-faktor seperti istilah yang sering dipahami masyarakat setempat, tingkat pendidikan, faktor geografi dsb. Delapan, agar pesan mudah diterima, perlu dipertimbangkan faktor rasionalitasnya. Informasi disampaikan secara konkret misalnya mengenai area yang terdampak, rentang waktu kerawanan bencana dsb. Sembilan, informasi hendaknya mudah diakses oleh semua orang.10)Informasi yang disampaikan hendaknya juga memberikan solusi bagi masyarakat sehingga komunikasi berlangsung efektif.

\section{Metode Penelitian}

Jenis penelitian ini adalah kualitatif deskriptif dengan subjek penelitian masyarakat di dusun Kalitengah Kidul, Desa Glagahharjo, Sleman Daerah Istimewa Yogyakarta. Pengumpulan data dilakukan dengan observasi dan wawancara. Observasi dilakukan terhadap lingkungan tempat tinggal masyarakat, pengamatan terhadap papan-papan petunjuk mitigasi bencana seperti panduan evakuasi, lokasi tempat warga berkumpul dalam kondisi siaga, lokasi hunian sementara, jalur evakuasi, lokasi menara pemantau aktivitas gunung dan sebagainya. Wawancara dilakukan kepada enam orang penduduk setempat dengan kriteria informan yang dipilih adalah penduduk yang telah tinggal diwilayah tersebut selama lebih dari dua puluh tahun sehingga sempat mengalami beberapa peristiwa aktivitas gunung Merapi. Validasi data dilakukan dengan melakukan wawancara kepada kepala dusun serta dengan mempelajari dokumen-dokumen yang relevan seperti panduan tertulis mengenai mitigasi bencana yang disusun oleh warga.

Analisis data dilakukan dengan melakukan koding terhadap hasil wawancara kemudian dilakukan analisis serta intepretasi hasil wawancara serta observasi dengan menggunakan konsepkonsep komunikasi. Keabsahan data 
dilakukan dengan proses triangulasi, yaitu dari hasil wawancara dengan informan masyarakat dan observasi lapangan dilakukan konfirmasi dengan kepala dusun, ketua RT, relawan dan dengan menggunakan konsep-konsep tentang mitigasi bencana. Dari proses ini, diperoleh gambaran yang utuh mengenai hasil wawancara dengan informan.

\section{Hasil Penelitian dan Pembahasan Deskripsi wilayah penelitian dan informan}

Dusun Kalitengah Kidul merupakan salah satu dari 10 Dusun di wilayah Desa Galagahharjo, Kabupaten Sleman Daerah Istimewa Yogyakarta. Batas wilayah dusun Kaltengah Kidul di bagian selatan berbatasan dengan Dusun Srunen, disebelah barat dengan Sungai Gendol, di sebelah utara dengan Dusun Kalitengah Wetan dan di sebelah Timur dengan Kota Yogyakarta. Dusun Kalitengahkidul terdiri dari 4 RT dengan jumlah kepala keluarga sebanyak 109 dan jumlah warga 315 orang. Alasan pemilihan desa ini adalah karena selain desa ini terdekat dengan puncak Merapi (+/- 5 $\mathrm{km}$ ) pada erupsi gunung berapi Merapi tahun 2010, tapi juga merupakan salah satu dari tiga wilayah di Kabupaten Sleman yang terparah dilanda bencana. Letusan Merapi pada tahun 2010 kekuatannya sekitar 4 VEI (Volcanic Explosivity Index, pada skala 8), dengan mengeluarkan 140 juta meter kubik material vulkanik.

\section{Perubahan komunikasi masyarakat sebelum dan setelah erupsi tahun 2010 Inovasi}

Dalam penelitian ini, inovasi adalah berbagai informasi baru mengenai mitigasi bencana, diantaranya adalah cara mengetahui informasi akan tanda-tanda potensi aktivitas gunung, siapa pihak yang dapat diandalkan untuk mengetahui status gunung. Informasi mengenai kapan harus mengungsi, kemana arah pengungsian, siapa yang menjadi prioritas untuk mengungsi, alat transportasi apa yang dapat digunakan untuk mengungsi, dokumen penting apa saja yang perlu dibawa saat mengungsi, siapa saja pihak yang dihubungi untuk dimintai bantuan.

\section{Saluran Komunikasi}

Beberapa hal penting dan merupakan inovasi baru bagi masyarakat setempat dalam menggunakan saluran informasi untuk mitigasi bencana antara lain adalah penggunaan alat komunikasi handy talkie dalam jumlah yang lebih banyak, pemanfaatan informasi dari data yang diperoleh melalui pemancar yang diterjemahkan dalam bentuk grafik, komunikasi kelompok, pembuatan standart operasional bencana, pembuatan tanda-tanda petunjuk evakuasi di beberapa wilayah strategis, dsb.

\section{Waktu}

Peristiwa erupsi gunung Merapi pada 2010 adalah waktu yang menentukan dan bersifat traumatis sehingga memungkinkan terjadinya proses difusi innovasi dalam mitigasi bencana. Setelah erupsi 2010, kesiapsiagaan bencana mengalami perubahan antara lain dengan adanya kordinasi yang lebih terorganisasikan, prioritas pengungsian yang lebih jelas tahapannya serta inisiatif warga yang lebih cepat tanggap. Hal ini sesuai dengan uraian Maloney dan Coppola bahwa suatu saat ketika masyarakat memperoleh 
informasi secara memadai tentang peringatan dini, maka mereka akan menerima dan memroses informasi yang akan membantu mereka mengambil tindakan yang tepat untuk mengurangi resiko dalam menghadapi bencana.

Dibandingkan erupsi 2006 dimana, masyarakat menganggap bahwa pengetahuan yang mereka percaya selama ini tentang perilaku Merapi masih dapat diandalkan. Oleh karenanya, atas dasar pengalaman dengan menggunakan pengamatan visual, kebiasaan, dan kepercayaan yang selama ini mereka anut, dianggap cukup. Selain itu, pada 2006, aktivitas gunung pun tidak menyebabkan masyarakat sampai harus mengungsi. Namun, dahsyatnya erupsi Merapi 2010 memberikan banyak perubahan terhadap pengetahuan, sikap dan tindakan masyarakat dalam mengadopsi inovasi baru dalam mitigasi bencana.

Setelah peristiwa bencana merapi pada 2010, masyarakat lebih menyiapkan diri dalam menghadapi bencana dengan memiliki alat komunikasi HT (handy talkie) dengan jumlah yang lebih banyak untuk setiap kelompok warga, rata-rata memiliki alat trasnportasi sepeda motor. Sebelum bencana erupsi 2010, hanya sedikit warga yang memiliki alat komunikasi HT, dan alat trasportasi. Pengalaman traumatik pada bencana erupsi 2010 membuat penduduk mememiliki kewaspadaan yang lebih tinggi serta sensitifitas yang lebih besar dalam menghadapi tanda-tanda bencana.

Sebelum peristiwa erupsi 2010, masyarakat setempat cenderung menyangsikan informasi yang disampaikan BPPTK (Balai Penyelidikan dan Pengembangan Teknologi Kegunungapian) mengenai status gunung berapi Merapi karena dalam pengamatan visual penduduk belum ada aktivitas gunung yang membuat mereka harus mengungsi. Oleh karena itu, warga cenderung menyangsikan perintah kepala dusun untuk bersiap-siap mengungsi. Kepercayaan masyarakat setempat terhadap aktivitas Merapi yang selama lebih dari 20 tahun tidak mengalami erupsi besar juga turut memperkuat sikap masyarakat dengan tidak langsung mengikuti informasi dari pihak yang berwenang. Perintah mengungsi baru diikuti beberapa hari setelah Merapi mengalami peningkatan aktivitas yang signifikan sehingga warga dengan dibantu relawan dan pemerintah akhirnya mau mengungsi pada saat-saat terakhir menjelang Merapi erupsi. Dalam proses pengungsian tersebut, ada 10 (sepuluh) orang meninggal, dan banyak warga yang tidak sempat menyelamatkan harta benda serta hewan ternak yang merupakan asset utama untuk membantu memperoleh nafkah sehari-hari.

Peristiwa erupsi 2010 yang menimbulkan pengalaman traumatik tersebut memberikan perubahan pemahaman bagi warga bahwa aktivitas merapi tidak hanya dapat dipahami berdasarkan kebiasaan yang dialami selama ini. Bahkan, masyarakat saat ini sudah dapat mempercayai bahwa pantauan merapi yang menggunakan teknologi lebih akurat daripada hanya mengandalkan pengamatan perilaku merapi dan pandangan visual.

Meskipun sebagian penduduk sudah memiliki alat komunikasi HT, tapi alat komunikasi sirine dan kentongan masih digunakan sebagai alat komunikasi yang diandalkan untuk menyampaikan informasi bahaya bencana. Beberapa rumah penduduk yang terletak jauh dari penduduk lain atau penduduk usia lansia 
mengandalkan alat komunikasi tersebut karena tidak memiliki HT atau tidak dapat menggunakan HT. Penggunaan handphone (hp) diangga tidak efektif karena terkendala akses sinyal.

Berikutnya hasil penelitian mengenai perubahan komunikasi masyarakat dalam menghadapi bencana sebelum dan setelah erupsi Merapi 2010, ditampilkan dalam tabel dibawah ini. Keterkaitan dengan konsep difusi inovasi bahwa uraian dalam setiap bagian memiliki elemen inovasi dimana terdapat ide-ide baru dalam mitigasi bencana, dan saluran komunikasi yang digunakan sementara elemen waktu terdapat pada pembagian waktu yaitu sebelum 2010 dan setelah 2010.

\begin{tabular}{|c|c|}
\hline Sebelum Erupsi Tahun 2010 & Setelah Erupsi Tahun 2010 \\
\hline $\begin{array}{l}\text { Tidak ada papan petunjuk mengenai jalur } \\
\text { evakuasi, lokasi titik kumpul, lokasi waspada } \\
\text { jalur yang dilalui awan panas, lokasi waspada } \\
\text { jalur yang dilalui lahar dan lokasi tempat } \\
\text { pengungsian serta lokasi tempat hunian } \\
\text { sementara }\end{array}$ & $\begin{array}{l}\text { Terdapat papan petunjuk mengenai jalur } \\
\text { evakuasi, titik kumpul dan tempat } \\
\text { pengungsian, namun bentuk papan belum } \\
\text { seragam dalam hal ukuran, warna, tulisan. } \\
\text { Papan informasi masih bersifat partial, } \\
\text { informasinya tidak utuh dan pada malam hari } \\
\text { sebagian besar petunjuk tidak terbaca. }\end{array}$ \\
\hline $\begin{array}{l}\text { Tidak terdapat panduan tertulis (manual) } \\
\text { bagi warga sebagai managemen informasi } \\
\text { kewasapadaan bencana. }\end{array}$ & $\begin{array}{l}\text { Sudah terdapat panduan tertulis (manual) } \\
\text { bagi warga sebagai managemen informasi } \\
\text { kewasapadaan bencana yang berisi data-data } \\
\text { penduduk serta peta informasi tentang } \\
\text { kebencanaan. }\end{array}$ \\
\hline $\begin{array}{l}\text { Tidak terdapat petunjuk dalam bentuk } \\
\text { gambar untuk petunjuk arah evakuasi } \\
\text { dilapangan. }\end{array}$ & $\begin{array}{l}\text { Baru ada sedikit petunjuk dalam bentuk } \\
\text { gambar tentang kewaspadaan bencana di } \\
\text { beberapa titik lokasi ditepi jalan utama. } \\
\text { Belum banyak terdapat papan petunjuk di } \\
\text { lokasi pelosok atau yang agak terpencil dari } \\
\text { jalan utama dusun. }\end{array}$ \\
\hline $\begin{array}{l}\text { Tidak terdapat petunjuk dilapangan untuk } \\
\text { memandu masyarakat ketempat } \\
\text { pengungsian atau memperoleh bantuan. }\end{array}$ & $\begin{array}{l}\text { Sudah terdapat beberapa petunjuk } \\
\text { dilapangan untuk memandu masyarakat } \\
\text { ketempat pengungsian atau memperoleh } \\
\text { bantuan. Namun bentuk petunjuknya tidak } \\
\text { standart atau berbeda-beda, terdiri dari } 4 \\
\text { warna, kuning, biru, putih, dan oranye dengan } \\
\text { ukuran papan serta huruf yang kecil dan } \\
\text { beberapa sudah memudar sehingga sulit } \\
\text { terbaca. }\end{array}$ \\
\hline
\end{tabular}




\begin{tabular}{|c|c|}
\hline Sebelum Erupsi Tahun 2010 & Setelah Erupsi Tahun 2010 \\
\hline $\begin{array}{l}\text { Sosialisasi mengenai bencana seperti dalam } \\
\text { bentuk simulasi jarang dilakukan, jikalaupun } \\
\text { ada dilakukan kurang intensif, warga } \\
\text { cenderung mengabaikan sosialisasi dari } \\
\text { BPPTK. }\end{array}$ & $\begin{array}{l}\text { Ada sosialisasi yang terjadwal baik dari kepala } \\
\text { dusun maupun pihak BPPTK }\end{array}$ \\
\hline $\begin{array}{l}\text { Tidak ada pertemuan warga secara rutin } \\
\text { membahas mengenai } \\
\text { menghadapi bencana. }\end{array}$ & $\begin{array}{l}\text { Terdapat pertemuan secara rutin membahas } \\
\text { mengenai kewaspadaan menghadapi bencana. }\end{array}$ \\
\hline $\begin{array}{l}\text { Belum ada kordinasi yang optimal dengan } \\
\text { kelompok dilingkungan RT dan RW } \\
\text { mengenai masyarakat yang perlu } \\
\text { diprioritaskan (balita, lansia, kaum difabel) } \\
\text { dalam menghadapi bencana. }\end{array}$ & $\begin{array}{l}\text { Sudah dibangun kordinasi antara kelompok } \\
\text { dilingkungan RT dan RW mengenai } \\
\text { masyarakat yang diprioritaskan dalam } \\
\text { penanganan bencana (orang cacat, lansia, } \\
\text { anak-anak, ibu hamil) }\end{array}$ \\
\hline $\begin{array}{l}\text { Pengambilan keputusan untuk mengungsi } \\
\text { tergantung informasi dari kepala dusun dan } \\
\text { kelompok tetangga sekitar tempat tinggal }\end{array}$ & $\begin{array}{l}\text { Mulai dapat mengambil keputusan sendiri } \\
\text { untuk mengungsi dengan mengandalkan } \\
\text { informasi dari pos pengawas dan BPPTK } \\
\text { (Balai Penyelidikan dan Pengembangan } \\
\text { Teknologi Kegunungapian). }\end{array}$ \\
\hline $\begin{array}{l}\text { Keputusan untuk menggunakan alat } \\
\text { ransportasi mengungsi menunggu informasi } \\
\text { dari kepala dusun atau ketua kelompok. }\end{array}$ & $\begin{array}{l}\text { Warga sudah dapat mengambil keputusan } \\
\text { tanpa menunggu informasi dari pihak lain } \\
\text { mengenai alat transportasi yang digunakan } \\
\text { untuk mengungsi. }\end{array}$ \\
\hline $\begin{array}{lrr}\text { Penggunaan HT sebagai alat komunikasi } \\
\text { diantara warga sangat minim, } & \text { untuk } \\
\text { berkordinasi dan mengetahui } & \text { status } \\
\text { waspada, hanya kepala dusun yang } \\
\text { memiliki }\end{array}$ & $\begin{array}{l}\text { Hampir setiap kelompok warga memiliki HT } \\
\text { untuk mengetahui status waspada gunung } \\
\text { dan saling berkordinasi pada saat terdapat } \\
\text { potensi bencana. }\end{array}$ \\
\hline $\begin{array}{l}\text { Penggunaan alat komunikasi tradisional } \\
\text { kentongan dengan memperhatikan nada } \\
\text { tertentu sebagai tanda bahaya. }\end{array}$ & $\begin{array}{l}\text { Penggunaan alat komunikasi tradisional } \\
\text { kentongan masih digunakan, namun untuk } \\
\text { radius tertentu dan bagi masyarakat yang } \\
\text { tidak dapat menggunakan HT (kaum lansia) }\end{array}$ \\
\hline $\begin{array}{l}\text { Informasi dari menara pemantau tidak selalu } \\
\text { menjadi andalan warga, karena seringkali } \\
\text { tidak berfungsi karena keterbatasan } \\
\text { peralatan dan operator. Selain itu status } \\
\text { gunung yang mulai menunjukkan aktivitas } \\
\text { erupsi dianggap normal. }\end{array}$ & $\begin{array}{l}\text { Informasi dari menara pemantau menjadi } \\
\text { andalan masyarakat karena konstruksi dan } \\
\text { fungsinya yang semakin optimal. Penggunaan } \\
\text { sirine ke masyarakat yang terhubung dengan } \\
\text { menara pemantau lebih dioptimalkan. }\end{array}$ \\
\hline
\end{tabular}

\section{Kesimpulan}

Pola komunikasi masyarakat di seputar Merapi telah mengalami berbagai perubahan sejak erupsi Merapi 2010 dibandingkan sebelumnya. Inovasi dalam komunikasi untuk mitigasi bencana membawa perubahan antara lain pada bentuk komunikasi kelompok, alat komunikasi yang digunakan, sikap masyarakat terhadap informasi yang disampaikan oleh pemerintah atau instansi resmi, hingga komunikasi yang menentukan pengambilan keputusan individu dalam proses evakuasi. Meskipun 
demikian, masih banyak komunikasi yang perlu diperbaiki dan ditingkatkan terait dengan mitigasi bencana.

Pada komunikasi kelompok, masyarakat mengalami perubahan yang semula sangat tergantung dengan informasi dari kelompok di sekitar tempat tinggalnya, kini masyarakat aktif mencari informasi sendiri. Jika sebelum erupsi 2010, masyarakat kurang mempercayai informasi dari luar seperti lembaga pemerintah atau relawan, maka setelah erupsi 2010 masyarakat lebih terbuka terhadap informasi dari luar. Kegiatan kelompok masyarakat juga diperkuat dengan adanya kegiatan penyusunan data penduduk terkait mitigasi bencana. Kelompok aktivitas masyarakat yang ada mulai terbuka terhadap berbagai informasi dari pemerintah sebagai informasi resmi dan ditindaklajuti dengan aktivitas mengungsi atas inisiatif sendiri.

Perubahan komunikasi juga memberikan dampak terhadap perubahan sikap dan perilaku masyarakat dalam mewaspadai bencana. Masyarakat setelah erupsi 2010 lebih memiliki kesiapan untuk mengambil keputusan mengungsi seperti mempersiapkan alat transportasi pribadi dan mempersiapkan dokumen-dokumen yang perlu dibawa saat mengungsi. Dalam hal informasi mengenai situasi siaga masyarakat, kini, lebih memiliki inisiatif dalam mencari informasi dam memiliki sikap lebih siaga seperti dapat menentukan kapan saatnya mengungsi tanpa harus diperintahkan berulangkali oleh kepala dusun. Masyarakat juga mengetahui prioritas siapa saja anggota keluarga yang harus diungsikan tanpa menunggu komando dari kepala dusun. Selain itu, masyarakat mengetahui juga pihak mana saja yang harus dihubungi untuk memperoleh bantuan.

Dari segi inovasi dalam saluran informasi mengenai bencana, masyarakat dan kepala dusun setempat telah menyusun panduan tertulis berisi data demografi penduduk yang terkait mitigasi bencana, misalnya, status tiap warga dari segi usia, kondisi fisik, alat transportasi yang dimiliki tiap keluarga, jumlah dan jenis ternak, alur pengungsian ternak, serta standart operasional evakuasi.

Alat komunikasi yang digunakan sebelum erupsi 2010 hanya mengandalkan informasi dari mulut ke mulut dan menggunakan alat tradisional kentongan serta sirine. Namun, setelah erupsi 2010, masyarakat mengandalkan alat komunikasi tambahan seperti HT (handy talkie) yang lebih banyak dimiliki disetiap RT serta senantiasa mengamati informasi dari menara pengawas gunung.

Berdasarkan kesimpulan tersebut, beberapa hal layak mendapatkan perhatian. Pertama, difusi untuk inovasi mitigasi bencana perlu dilakukan evaluasi secara berkala. Ini karena bencana letusan gunung seringkali tidak dapat diprediksi kapan tepatnya siklus srupsi akan terjadi, akibat dari bencana serta perilaku aktivitas gunungnyapun bisa berubah. Masyarakat senantiasa perlu diingatkan 
bahwa pengetahuan lokal atau tradisional yang selama menjadi acuan perlu dikombinasikan dengan inovasi teknologi sehingga informasi yang diperoleh menjadi lebih akurat. Kedua, penelitian ini memberikan beberapa rekomendasi untuk saluran komunikasi dalam mitigasi bencana gunung berapi. Pertama penting untuk dibuat papan petunjuk berupa informasi mengenai mitigasi bencana dibanyak lokasi dengan bentuk yang standar. Petunjuk tersebut harus mudah dibaca terutama dapat dibaca pada malam hari. Papan arah petunjuk hendaknya saling terintegrasi dengan lokasi penting lainnya seperti seperti titik kumpul, lokasi tempat tersedianya transportasi untuk mengungsi, tempat pengungsian, titik tempat hunian sementara, dan sebagainya. Media informasi tertulis dibuat dari bahan yang tidak mudah lekang karena cuaca dan tulisan atau gambarnya cepat pudar. Kedua, petunjuk mengenai jalur evakuasi dan mitigasi bencana hendaknya menggunakan bahasa yang istilahnya lazim dipahami serta digunakan masyarakat setempat. Penggunaan gambar yang akan lebih efektif karena sebagian masyarakat masih ada yang belum dapat membaca sehingga penggunaan gambar lebih mempermudah untuk mengingat. Ketiga, perlunya informasi mengenai tahapan tanda-tanda aktivitas gunung Merapi dalam bentuk gambar ataupun tulisan. Informasi dapat diletakkan di beberapa tempat umum seperti balai desa, masjid dan mushola atau tempat warga biasa berkumpul. Keempat, simulasi mengenai mitigasi bencana dalam kondisi normal perlu dilakukan secara rutin dan menggunakan berbagai macam cara agar menarik bagi masyarakat. Misalnya disampaikan pada saat pengajian rutin, dibuat dalam bentuk lomba tentang pengetahuan evakuasi, disampaikan dalam aktivitas belajar siswa disekolah, dalam bentuk permainan, sandiwara, pementasan wayang, cerita tradisional, pertukaran cerita dengan masyarakat dari dusun lain, dan sebagainya. Ketiga, perlunya dilakukan pemutakhiran data penduduk terkait dengan mitigasi bencana secara berkala dan disampaikan ke masyarakat sehingga meskipun dalam situasi normal masyarakat selalu dalam kondisi yang siap siaga dalam menghadapi ancaman bencana. 


\section{Daftar Pustaka}

\section{Carter,W.Nick (2008) Disaster Management : a disaster manager's handbook, Asian Development Bank, Philipines}

Hirokawa, Randy Y, dan Salazar, Abran J, 1999, Task Group Communication and Decision- Making Performance in Frey, Lawrence R, Goran, Dennis S dan Poole, Marshal Scott, 1999, The Handbook of Group Communication Theory, Sage Publication Inc.

Kusumasari, Bevaola \& Alam ,Quamrul (2011) Bridging the gaps: the role of local government capability and the management of a natural disaster in Bantul, Indonesia Published online: 10 November 2011 ! Springer Science+Business Media B.V. 2011Nat Hazards (2012) 60:761-779 DOI 10.1007/s11069-011-0016-1

Littlejohn, Stephen W., Karen A. Foss, editors (2009) Encyclopedia of Communication Theory. California: SAGE Publications, Inc.

Maloney, Erin K \& Coppola,Damon P (2009), Communicating Emergency Preparedness: strategic for creating a disaster resilient, Auerbach Publicationa Taylor \& Francis Group, USA

Mercer, Jessica, Kelman, Ilan \& Dekens, Julie (2009), Integrating Indigenues and Scientific Knowledge For Disaster Risk Reduction, dalam Takeuchi, Yukiko, Sharma, Anshu, Shaw Rajib, Natural Disaster Research, Prediction and Mitigation Series, Nova Science Publishers, Inc New York.

Miswanta, (2009), Problematika Penentuan Waktu Pengungsian, BPPTK,Pusat Vulkanologi dan Mitigasi Bencana Geologi, Badan Geologi .
Miller, Khaterine,2005, Communication Theories, Perspectives, Pocesses, and Context, 2nd edition, Mc Graw Hill International Edition

Polee, Marshal Scott (1999), Group Communication Theory, in Frey, Lawrence R, Goran, Dennis S dan Poole, Marshal Scott, 1999, The Handbook of Group Communication Theory, Sage Publication Inc.

Porifiev, Boris N, (1998) Issues in The Definition And Delineation of Disaster $\mathrm{s}$ and Disasters Areas in Quarantelli. E.L, What Is A Disaster?, Perspective on The Question, Routledge, New York

Pramono, Adi Suryo \& Birowo, M Antonius (editor), 2012. Hidup Nyaman Bersama Ancaman: Pengalaman Radio Komunitas Lintas Merapi, Klaten Jawa Tengah

Wijanarko, Himawan, (2006), Disaster Management di Negeri Rawan Bencana, The Jakarta Consulting Grup, Jakarta

Özerdem, Alpaslan \& Jacoby Tim,(2006), Disaster Management and Civil Society: Earthquake Relief in Japan, Turkey and India, I.B.Tauris \& Co Ltd, London

Rogers, Evertt M, (1995) Diffusion of Innovation, The Free Press, New York

Rogers, Evert M \&Kincaid, D Lawrence, 1981,Communication Networks, New York Free Press

Ritchie, L.David, (1991), Communication Concept 2: Information, Sage Publication, New Delhi

Sumadi, Dila (2007), Komunikasi Pembangunan, Pendekatan Terpadu, Bandung, Sembiosa Rekatama Media 
Sorensen, John H, Sorensen, Barbara Voght, 2006, Community Processes: Warning and Evacuation dalam Rodriguez, Havidan, Qaurantelli, Enrico l, Dynes, Rusell, Handbook of Disaster Research, Springer Science + Business Media, LLC, USA

Soemarwoto Otto, (2008), Ekologi, Lingkungan Hidup dan Pembangunan, Jakarta, Jambatan

Shaw, Rajib, Sharma Anshu, Takeuchi Yukiko,(2009) Indegenous Knowledge and Disaster Risk Reduction, from Practice to Policy, Nova Science Publishers, Inc, New York.

Sylves, Richard (2008) Disaster Policy and Politics, Emergency management and Homeland Security, CQ Press, Washington DC

\section{Tesis dan Laporan Penelitian}

Nugroho, Eko, Istiana Purwani (2012), Sistim Peringatan Dini Berbasis Masyarakat Untuk Mitigasi Bencana Merapi, Merapi Dalam Kajian Multidisiplin, Sekolah Pascasarjana UGM.

Setyarto, Dwiatmodjo Budi, (2012), Konflik Kebijakan dan Pengetahuan Lokal Dalam Pengurangan Risiko Bencana Erupsi Gunung Berapi Tahun 2010 di Kinahrejo/Palemsari, Desa Umbulharjo Kecamatan Cangkringan, Kabupaten Sleman, DIY. Pascasarjana Manajemen dan Kebijakan Publik Fakultas Ilmu Sosial dan Ilmu Politik Universitas Gadjah Mada Yogyakarta
Wirasuta, Dadang S (2013), Pelibatan TNI Dalam Penanggulangan Bencana Di Daerah Istimewa Yogyakarta, Laporan Hasil Penelitian, Lembaga Penelitian dan Pengabdian Masyarakat Universitas Pertahanan Indonesia, Jakarta

Kusumaningtyas, Purwanti, (2007), Intepretasi Ulang Makna spiritualitas bencana dalam cerita Rakyat Indonesia, Jurnal Kajian Politik Lokal dan Sosial, Humaniora, Volume 1 Tahun 2007.

\section{Artikel}

Martin R. Degg Martin and and K. David (2005) Seismic and Volcanic Hazards in Peru: Changing Attitudes to Disaster Mitigation, The Geographical Journal, Vol. 171, No. 2 (Jun., 2005), pp. 125145Published by: Wiley on behalf of The Royal Geographical Society with the Institute of British Geographers

Oman Abdurahman, Eddy Mulyadi, Priatna, Prima M. Hilman, Joko Parwata dkk (2006) , Karsima Gunung Merapi, dari Internet ke Dunia Nyata, artikel Refleksi Untuk Penyajian Informasi dan Mitigasi Bencana Gunung Api, Warta Geologi, Mei 2006 


\section{Berita Koran}

Kompas,05-11-2010 halaman 48, Adaptasi Mengubah Paradigma Mengatasi Bencana Oleh BE Julianery

"Asia Paling Banyak Dilanda Bencana," Kompas, 20 Okotober 2012

"Bencana Gunung Api: Penduduk Indonesia Paling Terancam," Kompas, 13 April 2014

"Manajemen Bencana Mendorong Mitigasi Bencana Berbasis Resiko," Kompas, 20 Desember 2010

"Gunung Api: Dua Abad Letusan Tambora," Kompas o5 April 2015

\section{Sumber lain}

Undang-Undang Republik Indonesia Nomor 24 Tahun 2007 tentang Penanggulangan Bencana

Peraturan Presiden Republik Indonesia Nomor 8 Tahun 2008 Tentang Badan Nasional Penanggulangan Bencana

Dokumen Tim Pengurangan Resiko Bencana Parikesit, 2014, Sumber Matriks Data Kependudukan Aset dan SOP Dusun KalitengahKidul Desa GalagahHarjo Kabupaten Sleman, Daerah Istimewa Yogyakarta. 